\title{
Conservar na palma o peso de uma mão: ritmo, lirismo e memória em João Cabral de Melo Neto
}

\author{
Keep the weight of a hand in your \\ palm: rhythm, lyricism and memory \\ in João Cabral de Melo Neto
}

Francine Fernandes Weiss Ricieri ${ }^{1}$

RESUMO

Este ensaio propõe, por intermédio de uma leitura cerrada do poema "O Engenheiro", do livro homônimo de João Cabral de Melo Neto, o reexame de alguns dos conceitos estabelecidos pela recepção crítica ao poeta como relevantes para o pensamento sobre sua poesia. Ao final, uma breve incursão por um segundo poema ("Uma faca só lâmina”) oportuniza o estabelecimento de algumas reflexões finais.

Palavras-chave: João Cabral de Melo Neto; lirismo; ritmo; memória.

\section{ABSTRACT}

This article proposes, through a close reading of the poem "O Engenheiro" (The Engineer), from the book of the same title by João Cabral de Melo Neto, the reexamination of some of the concepts established by the critical reception to the poet as relevant to the thought about his poetry. At the end, a brief incursion into a second poem ("Uma faca só lâmina") ("A knife only blade") allows the establishment of some final reflections.

Keywords: João Cabral de Melo Neto; lyricism; rythm; memory.

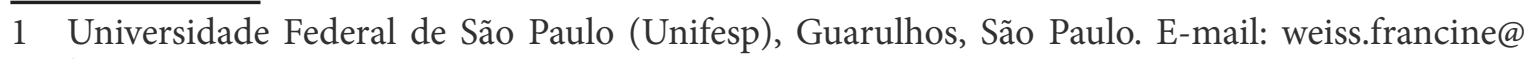
unifesp.br 
“(...) o rastro tem ainda isto de excepcional em relação a outros signos: ele significa fora de toda intenção de significar [de faire signe] e fora de todo projeto do qual ele seria a visada. [...] O rastro autêntico [...] decompõe a ordem do mundo; vem como em 'sobre-impressão'. Sua significância original desenha-se na marca impressa que deixa, por exemplo, aquele que quis apagar seus rastros, no cuidado de realizar um crime perfeito."

(Emmanuel Levinas, Humanismo do outro homem)

“Crimes da terra, como perdoá-los?

Tomei parte em muitos, outros escondi.

Alguns achei belos, foram publicados."

(Carlos Drummond de Andrade, "A flor e a náusea”)

“A emoção tem má reputação."

(Michel Collot, A matéria-emoção) 


\section{F. F. W. RICIERI}

Conservar na palma o peso de uma mão: ritmo, lirismo e memória em João Cabral de Melo Neto

\section{Primeiros movimentos}

$\mathrm{O}$ título escolhido para o terceiro livro publicado por João Cabral de Melo Neto, em 1945, é também, como se sabe, o título de um dos poemas lá contidos. É, ainda, com variações, um dos mais recorrentes epítetos ou qualificativos dentre aqueles aos quais críticos podem recorrer quando escrevem sobre aquele poeta. Um artigo que estudou aspectos do processo criativo de Cabral "à luz de seus manuscritos" fornecia, há alguns anos, um sucinto (mas suficiente) histórico da gênese também dessa que se tornou uma fórmula de referência, convertida em chave de leitura e, eventualmente, obstáculo à observação: enquanto os poemas de Pedra do Sono (1942) não poderiam ser descritos como "um edifício racionalista" (Antonio Candido), o título desse terceiro livro seria aquele que melhor exprimiria a poética em questão (àquela altura, claro). A designação será reatualizada com pequenas adequações naqueles textos usualmente considerados "fundadores" dos paradigmas que logo se assentaram, quanto à leitura especializada do escritor. ${ }^{2}$ Será, também, objeto de análise pelo próprio João Cabral, seja no montante mais amplo da parcela propriamente poética de seus escritos, seja em alguns textos com perfil teórico ou ensaístico, de que sua trajetória literária se fez acompanhar.

Talvez não seja ocioso reexaminar o poema:

\section{$O$ engenheiro}

A Antônio B. Baltar
Revista Letras,

Curitiba, UFPR, n. 102, pp. 171-197, jul./dez. 2020 ISSN 2236-0999 (versão eletrônica)

\begin{abstract}
A luz, o sol, o ar livre
envolvem o sonho do engenheiro.

O engenheiro sonha coisas claras:

superfícies, tênis, um copo de água.

O lápis, o esquadro, o papel;

o desenho, o projeto, o número:

o engenheiro pensa o mundo justo,

mundo que nenhum véu encobre.
\end{abstract}

(Em certas tardes nós subíamos

ao edifício. A cidade diária,

como um jornal que todos liam,

ganhava um pulmão de cimento e vidro).

2 Para a recuperação das referências e do histórico mencionado, sugere-se a leitura das páginas 129 a 131 de: ROCHA, Francisco J. G.L. O canteiro do poeta-arquiteto: a conduta criativa de João Cabral de Melo Neto à luz de seus manuscritos. Revista IEB, São Paulo, n. 55, p. 127-147, 2012. 


\begin{abstract}
A água, o vento, a claridade,
de um lado o rio, no alto as nuvens,

situavam na natureza o edifício

crescendo de suas forças simples.
\end{abstract}

Considerando-se o engenheiro e o edifício como metáforas críticas fundantes em uma vasta e diversificada recepção, duas questões parecem se colocar, já a uma primeira leitura: como o poema se inscreve no tempo e no espaço? como o tempo e o espaço foram inscritos no poema? De saída, a começar pelo exame dos tempos verbais, pode-se registrar que as duas primeiras estrofes se organizam a partir de verbos no presente do indicativo. $\mathrm{Na}$ estrofe de abertura, os versos 1 e 4 presentificam um arranjo visual e rítmico que "emoldura" a figura que o título designava como central: aí, o engenheiro é paradoxalmente um homem que sonha e um homem que sonha "coisas claras". Luz, sol, ar livre envolvem o sonho do engenheiro, tomado por imagensqueremetemaelementosdanatureza. Noúltimoversodaestrofe,osdois pontos introduzem aquilo com que se sonha: resultantes do trabalho humano.

No segundo caso, a formulação daquilo de que se aproxima o sonho (aquilo com que se sonha), a partir de elementos que implicam o trabalho humano, permitiria talvez introduzir, como que entre parênteses, uma reflexão sobre divisão proposta por João Cabral em uma "tese" escrita para o Congresso de Poesia do Recife (1941). Lá, após breve introdução, o autor recupera a alusão generalizada ao "sono como trampolim para o sonho, essa fuga efetiva do homem às dimensões comuns do seu mundo", para se posicionar quanto 174 ao objeto central de suas preocupações: "Eu tentaria aqui falar do sono em suas relações com a poesia (relações secretas, porém não apenas: suspeitas), do sono como fone do poema".4 Talvez seja relevante não desprezar a epígrafe escolhida para o ensaio - fragmento de um poema de Willy Lewin —, que

3 O paradoxo viria de uma associação também recorrente entre algumas imagens do primeiro livro e outras que, no terceiro, a ele poderiam talvez ser contrapostas. Benedito Nunes assim formula certa tensão entre passividade e ação associável aos conteúdos oníricos de Pedra do Sono: "Essa reação reflexiva ao desfile não consentido, mecânico e aleatório das imagens permite-nos constatar que só uma parte do sujeito da experiência, aquela que o EU desperto vê como "vulto longínquo / de um homem dormindo", deixase envolver pelas metamorfoses do espírito adormecido. A outra, que consente ao sonho, imprime-lhe um ritmo de farsa, que mais salienta o lado risível, cômico, das aparições imprevistas que o assediam: manequins corcundas, telefones com asas e arranjos de patins." (NUNES, 2007, p. 15-16) Antonio Carlos Secchin acrescentaria: "O discurso cabralino em seu momento de "sono"- (...) elegerá o noturno e o sombrio para endossar o espaço onírico (...).”(SECCHIN, 1985, p. 18) Nesse sentido, quanto às imagens relativas ao sonho, tal como formuladas no livro inaugural, seria possível discernir alguma oscilação entre o consentido e o não consentido, acrescendo-se, ainda, um predomínio (não exclusividade) de elementos noturnos e sombrios (a serem opostos a uma opção pela "claridade" e pelas imagens diurnas, em escritos posteriores). Em relação a essas formulações, de que não discordo, aponto como "paradoxal" um sonho com "coisas claras". Paradoxal em relação a uma expectativa estabelecida a partir da leitura do livro inicial e dos aspectos que se desenvolvem na sequência.

4 MELO NETO, 1994, p. 687. 


\section{F. F. W. RICIERI}

Conservar na palma o peso de uma mão: ritmo, lirismo e memória em João Cabral de Melo Neto conjuga alguns elementos que serão retomados adiante: "um mundo informe e absurdo" (o material onírico) provocando específicos efeitos (lágrimas? um específico estado de espírito?) em uma subjetividade nos versos constituída. ${ }^{5}$ Enfatizo, ainda, o elemento de reflexão sobre o ato criador, um fim perseguido pelo, então, jovem poeta (perseguição nunca abandonada):

O que eu procurei, tentando assinalar o modo como o sonho enche a vida de nosso tempo, foi apenas fazer uma constatação que vejo como um dos argumentos para chegar ao fim que persigo. Refiro-me a isso que, como a obra de arte, o sonho é uma coisa sobre a qual se pode exercer uma crítica. O sonho é como uma obra nossa. Uma obra nascida do sono, feita para nosso uso. O sonho é uma coisa que pode ser evocada, que se evoca. Cuja exploração fazemos através da memória. Um poema que nos comoverá todas as vezes que sobre nós exercermos um esforço de reconstituição. Porque é preciso lembrar que o sonho é uma obra cumprida, uma obra em si. Que se assiste. Esta fabulosa experiência pode ser evocada, narrada. Como a poesia, ou por outra, em virtude da poesia que ela traz consigo, apenas pode ser transmitida. ${ }^{6}$

Os parênteses prestam-se, de início, ao trabalho de problematizar a dupla incidência de sonho (como verbo e como substantivo) na abertura do poema. Prestam-se, ainda, ao desvelamento de uma das questões que abrem esse texto e que diz respeito exatamente ao problema do tempo. O sonho é aí pensado, entre outros elementos, por aquilo que nele se pode associar à narração: a narração desdobra-se no tempo. ${ }^{7} \mathrm{O}$ trecho situa, ainda, outras perspectivas: a exploração do sonho demanda um trabalho de evocação. Demanda deslocamentos no tempo. As associações são múltiplas: sonho, exercício crítico, evocação, reconstituição, memória, obra. Voltaremos a elas.

Considerando, portanto, que já a alusão a sonho implica o problema do tempo, talvez seja o caso de retomar os modos como o poema se espacializa, ou suas relações com o espaço. Ainda na primeira estrofe, duas estruturas enumerativas similares se constituem a partir de três substantivos em sequência (nos versos um e quatro), interrompidos por vírgula, em movimento

\footnotetext{
5 Transcrevo:

"O sono, um mar de onde nasce

Um mundo informe e absurdo,

Vem molhar a minha face:

Caio num ponto morto e surdo." Willy Levin

Para uma introdução às relações entre Cabral e seu contemporâneo e amigo, Willy Levin, remeto ao trabalho de José Roberto de Araújo Godoy (2009, p. 20-23).

6 MELO NETO, 1994, p. 686.

7 Muito sinteticamente, recorro a Hélio Salles Gentil, apresentando a edição brasileira de Tempo e Narrativa, de Paul Ricoeur: "A tese fundamental, fundadora de todo o empreendimento, é forte: é a narrativa que torna acessível a experiência humana do tempo, o tempo só se torna humano através da narrativa." (GENTIL, 2012, p. xi).
}

Revista Letras,

Curitiba, UFPR, n. 102, pp. 171-197, jul./dez. 2020 ISSN 2236-0999 (versão eletrônica) 
entrecortado, acrescendo-se, ainda, ao último termo uma adjetivação (como um tipo de acento, uma forma de intensificação). Intercalam-se duas construções sintáticas ritmicamente equivalentes: a) verbo + objeto + complemento nominal; b) sujeito + verbo + objeto. Assim, os quatro blocos semânticos e sonoros (versos) organizam-se como estruturas ternárias (uma estrutura ternária por verso). Nos versos mediais, o ritmo ternário é fluido, fluente (sem marcas de pontuação ou outros obstáculos que possam interromper ou cadenciar o deslizamento). Nas extremidades, entrecortado. As "coisas claras" do verso 3 parecem equivaler (semanticamente) ao sujeito composto do verso 1 , o que também redimensiona a união do conjunto - os modos de ordenação rítmicos ${ }^{8}$ alternam, não separam.

$\mathrm{Na}$ primeira construção, o engenheiro aparece em posição de passividade (o sonho não consentido envolvido pelos elementos naturais), passando, na formulação seguinte, à posição ativa (consentida?). A construção "sonhar coisas claras" levaria, assim, a uma possibilidade de alteração (ou de tensionamento) dos sentidos atribuíveis ao verbo (em contraponto com o substantivo): sonhar pode, então, remeter a conotações como desejar, almejar, pretender, projetar. O presente do indicativo parece sugerir, ainda, uma descrição em processo e o engenheiro que se descreve constitui-se por seu sonho (na segunda estrofe, parece mais explícita a alusão a desejos ou projetos) e pelos elementos em que esse sonho se concretiza. $\mathrm{O}$ engenheiro se delineia nas coisas de que se edifica sua identidade no poema. $\mathrm{O}$ engenheiro se edifica por analogias.

Há uma relação de contiguidade entre as estrofes 1 e 2 , não apenas porque os verbos (no segundo caso) permanecem no presente do indicativo, mas também porque a ordenação ternária dos elementos se reapresenta, com as mesmas marcações (acentos) impostos por expressões com valor adjetivo em posições específicas. Os versos 1 e 2, agora, constituem enumerações simples: dois processos enumerativos encenam-se diante do leitor associados, ainda, àquela figura humana, o engenheiro. O engenheiro ordenaria a

8 O ritmo pode ser pensado como um conjunto complexo de interações de elementos, que vai além da análise métrica, incluindo recorrências, pausas, suspensões, desvios de curso, assonâncias, aliterações, anadiploses, anáforas, paralelismos sintáticos ou de outra ordem. Como entende Rogério Chociay: “(...) o que entendemos por ritmo é justamente a resultante percebida da solidariedade desses níveis da linguagem que encorpam o poema; profundamente arraigado à expressão, não surge devido a um aprendizado de preceitos, mas ao próprio dinamismo criador e verbalizador do artista. É, antes de tudo, percebido, sentido, e não como efeitos parciais ou colaterais, mas como uma resultante global. Podemse indicar pistas, elucidar detalhes, apontar aspectos para melhor apreciá-lo, mas, ao fim, dele restará sempre um quantum tão imensurável como a própria expressão poética a que se irmana. O metro representa apenas a abstração de um dos apoios rítmicos do poema (...)". (CHOCIAY, 1974, p. 2) Mary-Ann Caws, por outro lado, propôs, também, a consideração do elemento rítmico a partir do modo de ordenação e das relações entre estrofes ou divisões de um poema em segmentos. Para a autora, poemas podem ser lidos pelas conexões estabelecidas entre suas partes, pela alternância de momentos de maior ou menor intensidade, por núcleos de concentração semântica (ou sonora), pela produção de silêncio ou interrupções, entre outros fatores rítmicos. Ver: CAWS, 1996. 


\section{F. F. W. RICIERI}

Conservar na palma o peso de uma mão: ritmo, lirismo e memória em João Cabral de Melo Neto

disposição (a seleção) de recursos (ou instrumentos) no verso inicial. O engenheiro quantificaria, projetaria, desenharia, no segundo verso, em uma sequência de ações que, em conexão com o verso anterior, implicitam noções como cálculo, trabalho, projeção.

$\mathrm{Na}$ mesma estrofe, também os versos 3 e 4 são estruturas sintáticas ternárias. Rearranjando o modelo da estrofe anterior, esta se abre com dois versos em ritmo entrecortado, fechando-se por dois versos em ritmo fluente (sem interrupções como aquelas proporcionadas pelas vírgulas das enumerações). Na primeira, descreveu-se uma ênfase ritmicamente inserida no texto pelos elementos com valor adjetivo (ar livre, copo de água). Nessa segunda estrofe, tais elementos se deslocam para a segunda modalidade construtiva e as adjetivações recaem, nas duas vezes, sobre o substantivo "mundo". A primeira formulação, no verso 3 , é análoga às que apareceram na estrofe anterior (sujeito + verbo + objeto) ${ }^{9}$, mas a segunda complica-se sintaticamente.

Se, em um caso, mundo é o objeto da ação de pensar do engenheiro (verso 3) - e se trata de um mundo justo —, no outro, uma oração de valor adjetivo relativa ao mesmo substantivo (mundo) permite que esse substantivo, que agora (não) receberia a ação de encobrir (efetuada por "nenhum véu"), seja posicionado enfaticamente na abertura, em anadiplose em relação ao verso anterior (reduplicando o que se fizera com "engenheiro", na primeira estrofe). Então, se o engenheiro antes transitava da passividade para a ação (e a repetição dava destaque a isso), mundo só aparentemente se desloca (como a recorrência da anadiplose poderia sugerir $)^{10}$, mantendo-se rigorosamente dependente da ação de pensar perpetrada pelo engenheiro: aproximações e separações (ritmo).

Talvez seja possível apontar, ainda, uma dissonância, além de outras que se vão reordenando ao longo dos versos, entre a atividade projetada (projetável) e o pensamento que se volta para um "mundo justo". Qual correlação se pode estabelecer entre o pensamento do "mundo justo" e o cálculo (o projeto) dos dois primeiros versos? Por que mundo justo, se pode haver, é construção em tudo diversa daquela que se pode arquitetar em uma prancheta, em uma mesa de trabalho, entre esquadros e folhas de papel. $\mathrm{O}$ homem racional (esse ser de números e cálculos) enuncia-se, assim, também, a partir de uma específica projeção fantasiosa (pode haver algo mais utópico que mundo justo?).

$\mathrm{O}$ "mundo justo" (elemento externo à subjetividade em elaboração no processo enunciativo do poema), saliente-se, é uma projeção por meio da

9 Em "o engenheiro pensa o mundo justo", considerou-se o uso do verbo pensar como transitivo direto.

10 Esse procedimento pode produzir o efeito de frustrar expectativas. Digamos que o mesmo recurso repetido pode levar à dedução de que haverá coincidência ou proximidade semântica. Não é o que ocorre. 
qual podemos constituir (acrescer um traço à constituição de) um homem que aí se caracteriza. O engenheiro, de resto, não pensa apenas "o mundo justo", pensa-o como elemento "que nenhum véu encobre". A imaginação crítica poderia, eventualmente, recuperar a propósito deste "véu", como reminiscência indireta, a epígrafe de $A$ relíquia: "Sobre a nudez forte da verdade, o manto diáfano da fantasia”. E, dessa associação indireta (resultado da subjetividade crítica implicada, saliente-se), seria possível construir um rosário extenso de contas e derivações.

Não é propósito deste texto seguir por esse caminho, senão apontando que "mundo justo", neste específico poema, dificilmente poderia ser associado a algo como a "nudez forte da verdade" (pois onde houve mundo justo que a palavra escrita pudesse denunciar?), não sendo também, pela própria sintaxe dos versos, associável a qualquer tipo de véu encobridor. De onde talvez se possa derivar a hipótese de que o elemento que não se pode encobrir seja o desejo de um mundo justo, só localizável da perspectiva de uma específica subjetividade, a daquele engenheiro: que calcula e projeta efeitos (enquanto) pensa o mundo justo. Enquanto não pode encobrir ou deixar de enunciar essa projeção - que em tudo modifica a questão: de qual engenheiro estaríamos tratando aqui?

Esse engenheiro, homem dado a utopias ${ }^{11}$, na quarta estrofe fará um segundo movimento (outra dissonância?), deslocando-se do espaço administrado de sua oficina para o campo aberto da "natureza" e trazendo à cena elementos imprevisíveis (não passíveis de ordenação, cálculo ou controle) como água, vento, claridade, rio e nuvens. Mas se, na primeira estrofe, tínhamos duas sequências enumerativas contando cada uma com três elementos, nesse caso, a segunda enumeração só se completa precisamente com "edifício". Água, vento, claridade. Rio, nuvens, edifício. A dissonância é e não é: o terceiro verso exatamente propõe um tal edifício em que algo que seja da ordem da natureza se possa atualizar. Um edifício que possa "crescer" (como uma planta?) de suas forças simples (forças da natureza?). As mesmas pelas quais se movem os demais elementos (água, vento, claridade, rio e nuvens)?

As duas primeiras estrofes podem ter, ainda, modos de estruturação ternária de ordem semântica em seu conjunto:

A luz, o sol, o ar livre

envolvem o sonho do engenheiro.

11 Indico alguns estudos que se dedicam à consideração das relações entre esse poema e o "onirismo utopista de Le Corbusier", bem como às relações entre arquitetura e natureza, temas que não serão aqui desenvolvidos. O primeiro é o livro de Cristina Henriques da Costa, Imaginando João Cabral Imaginando (2014, p. 239 a 244). O segundo, a dissertação de Gustavo S. Saldivar (2012), voltada às relações entre a poesia de João Cabral e a arquitetura moderna. A tese de doutorado de Eucanaã Ferraz (2000) constitui, por fim, referência decisiva quanto a essas questões. 


\section{F. F. W. RICIERI}

Conservar na palma o peso de uma mão: ritmo, lirismo e memória em João Cabral de Melo Neto

\author{
O engenheiro sonha coisas claras: \\ superfícies, tênis, um copo de água. \\ O lápis, o esquadro, o papel; \\ o desenho, o projeto, o número: \\ o engenheiro pensa o mundo justo, \\ mundo que nenhum véu encobre.
}

Primeira estrofe: elementos da natureza; o sonho e o sonhar do engenheiro; elementos de construção humana. Segunda estrofe: instrumentos/ materiais; ações projetivas; sonhos ou desejos do engenheiro. E, na quarta estrofe, um tipo similar de paralelismo talvez pudesse ser tentado: no verso 1, elementos primários (água, vento, claridade); nos versos 2 e 3, elementos complexos (rio, nuvens, edifício); nos versos 3 e 4, um elemento abstrato uma força ou as forças simples da natureza manifestando-se em ou a partir de aqueles outros constituintes. As forças simples da natureza incidindo e movendo água, vento e luz, compondo e rearranjando rio e nuvens. A um edifício associável a um tal processo, portanto, é que o poema se refere. Um edifício simples e móvel como aqueles outros componentes. Como o desejo (que é sempre desejo de alguém), o edifício se edifica pela ação de mãos humanas (ou máquinas por elas conduzidas), a partir de forças da natureza, crescendo como um organismo - em simplicidade dependente, ainda, da avaliação de alguém.

\section{Uma interposição}

Ocorre, em acréscimo, que esse poema é um edifício de quatro estrofes. $\mathrm{E}$ a estrofe 3 começa por se afastar das duas primeiras pelo tempo verbal que organiza o conjunto de quatro versos: o pretérito imperfeito do indicativo que, sendo o tempo da duração pretérita e também o tempo das lendas e das fábulas, é o tempo por excelência da rememoração de um estado habitual no passado. Se as duas primeiras estrofes se escreviam no presente, essa terceira, no imperfeito, insere no processo poético um deslocamento temporal. Que se faz acompanhar de uma não desprezível mudança sintática, rítmica, de tom. Os esquemas ternários (de certo modo um tanto mecânicos) agora terão volteios mais complexos.

A estrofe se divide em dois períodos constituídos por duas orações principais e uma subordinada (intercalada no segundo período, o maior). Outra diferença: os núcleos semânticos não se fecham a cada verso ou a cada par de versos (sequenciados ou intercalados). Os períodos deslizam de um verso ao seguinte e fluem sem interrupções (onde poderia ter havido uma vírgula, como após o vocábulo "tardes", no verso 1), ou com interrupções
Revista Letras,

Curitiba, UFPR, n. 102, pp. 171-197, jul./dez. 2020 ISSN 2236-0999 (versão eletrônica) 
relativas (como as vírgulas que marcam a intercalação de oração). A segunda parte do verso 2, por outro lado, projeta seu sentido ao 4, o que é, ainda, dificultado pela interposição oracional. A exceção é o verso 2: nele os dois períodos se separam de modo abrupto por um ponto e a divisão não tem proporções equilibradas, como nas demais estrofes. Ela separa um verso e meio de dois e meio, aproximadamente. Após "edifício", portanto, o ponto impõe uma pausa mais marcada, uma necessária interrupção na leitura: a "cesura". ${ }^{12}$

De uma perspectiva que combine princípios silábicos e silábicoacentuais, o primeiro verso organizaria sua alternância entre tônicas e átonas de modo a resultar em quatro iambos sequenciados ${ }^{13}$. No verso 2 , teríamos dois iambos seguidos por dois anapestos. No verso 3, um troqueu (em inversão do iambo) e outros três iambos. No verso 4, um iambo, dois anapestos e um iambo. Ainda nos versos 1 e 2, seriam possíveis deslocamentos das tônicas para as sílabas iniciais, em uma leitura que acentuasse a abertura de cada verso. Uma tal leitura proporcionaria um efeito de aproximação sonora entre os versos, fazendo com que os três primeiros fossem lidos como se iniciando pelo par: troqueu seguido de iambo.

\footnotetext{
12 Recorrendo ao e-dicionário de Carlos Ceia: "Pausa no interior de um verso. Na métrica tradicional, esta pausa era obrigatória, sendo ditada pelo ritmo imposto ao verso. Não deve ser confundida com pausa de leitura, que é variável de leitor para leitor. Os versos curtos (até cinco sílabas) não estão, normalmente, sujeitos a cesura. Nos versos longos, pode ocorrer no princípio ("Cantei; || mas se me alguém pergunta quando", Camões), no meio ("é ferida que dói, || e não se sente", Camões) ou perto do fim do verso ("enquanto não quiserdes vós, || Senhora”, Camões). A posição medial é a mais comum. É possível um verso conter mais do que uma cesura ("olhe o céu, || olhe a terra, || ou olhe o mar", Sá de Miranda). A cesura é muitas vezes marcada pela pontuação.” In: https:/edtl.fcsh.unl.pt/encyclopedia/ cesura/

Observo que podemos, ainda, apontar cesuras, considerada essa definição, nos versos 1 e 4 da primeira estrofe e 1 e 2 , da segunda estrofe, de modo aproximável ao que ocorre no verso citado de Sá de Miranda. Também seria possível considerar o emprego de cesura nos versos 1 e 2 da quarta estrofe.

13 Polemizando com Wolfgang Kayser, Péricles Eugênio da Silva Ramos defende a rentabilidade analítica da adoção dos princípios silábico e silábico-acentual para a descrição métrica em língua portuguesa: “Certos versos em determinados períodos (...) quase que só determinaram composições silábico-acentuais; e noutros períodos, em que tem prevalecido a tendência silábica, ainda assim um ou outro poeta, seguindo as suas próprias inclinações tem feito de versos usualmente silábicos composições silábico-acentuais. (RAMOS, 1959, p. 30-31) Quanto à aplicabilidade da descrição silábico-acentual para pensarmos poemas de João Cabral de Melo Neto, acompanho pressupostos enunciados por Paulo Henriques Britto, que vem recorrendo a esse tipo de análise para pensar outros poetas do século XX. Em especial em artigo que comento na sequência. (BRITTO, 2014).
} 


\section{F. F. W. RICIERI}

Conservar na

palma o peso de

uma mão: ritmo,

lirismo e memória em João Cabral de Melo Neto

Aproximando esses três versos, deixaríamos o quarto em dissonância: o que é também da ordem do ritmo. ${ }^{14}$ Por outro lado, os versos 1 e 3 são octossilábicos (formados ambos pela sequência 1 troqueu e 3 iambos - admitindo-se a tensão mencionada; ou 4 iambos no verso 1 , se a desconsiderarmos). E os versos 2 e 4 também podem ser lidos em homofonia: dez sílabas no último e, no segundo, admitida a cesura apontada, seria possível a leitura de quatro sílabas no primeiro hemistíquio (com o desprezo da átona final previsto em tratados de metrificação), havendo seis outras sílabas após os pontos. Essas aproximações previstas em tratados (como incluir na contagem uma sílaba do verso anterior, desprezar átonas após o hemistíquio, relativizar hiatos e ditongos), servem para demonstrar apenas que, por vezes, um verso não "perfeito" do ponto de vista da simples contagem, tem um andamento equivalente ao de outro, mais regular. Assim, aquele jogo de intercalações que, nas estrofes 1 e 2, entrelaçava os diferentes versos, pode ser reproduzido, no caso dessa estrofe, pelas relações de semelhança (ou diferença) propriamente métricas e acentuais entre os versos. ${ }^{15}$

Parece haver, ainda, um efeito indireto que não deixa de ser curioso. Nos versos 2 e 3, se for feita a leitura sugerida (com deslocamento da tônica para a sílaba inicial), o trecho inicialmente seguinte pode soar como anapesto. Nesse caso, passaríamos a ter andamento binário ${ }^{16}$ entre átonas e tônicas, com produção de sintagmas completos, apenas em dois específicos trechos do poema (grifo as tônicas, para clareza): "em certas tardes nós subíamos" e "que todos liam". Ainda que toda a estrofe opere um importante

14 Em seu conjunto, o poema "O engenheiro" é composto por versos polimétricos. Assim distribuídos (desconsidero a terceira estrofe, comentada no texto): na primeira estrofe, um verso de seis sílabas seguido por três decassílabos; na segunda, três versos octossilábicos, sendo o terceiro verso um decassílabo (distribuição idêntica à que ocorre na última estrofe, apenas com alterações acentuais). Versos polimétricos são entendidos, aqui, nos termos propostos por Paulo Henriques Britto: "Uma outra opção, que venho tentando explorar (...), é entender "verso livre" como o nome não de um tipo específico de verso, mas de todo um continuum de formas cujos pontos extremos são, de um lado, o verso polimétrico, e, de outro, práticas poéticas que abrem mão do verso, das quais a poesia concreta é a mais importante no Brasil. O que todas essas formas teriam em comum seria a utilização consciente do que chamaremos de ritmo como um dos mais importantes princípios organizadores da escrita, porém sem recorrer a um padrão métrico fixo. "Ritmo" é entendido aqui como "a figure of periodicity, any sequence of events or objects perceptible as a distinct pattern capable of repetition and variation" [uma figura de periodicidade, qualquer sequência de eventos ou objetos perceptível como um padrão distinto, capaz de repetição e variação] (Preminger e Brogan 1993: 1066-1067). (BRITTO, 2014, p. 30) Grifo meu.

15 Flora Sussekind assim abordou a questão do ritmo (nos termos aqui propostos), em João Cabral: "Basta pensar, porém, na sua difícil opção pela rima toante e na troca propositada do decassílabo e do verso de sete sílabas, habituais no Brasil, pelo trabalho com versos de oito sílabas, para perceber que essa reiterada anti-musicalidade, essa incapacidade de fonética, de que fala, e costuma estender à comunicação oral em geral (...), são muito mais formas de enfatizar um afastamento da vertente mais "oratória" da literatura brasileira, e de afirmar, em oposição, uma primazia da visualidade sobre a melodia, e a uma compreensão da poesia como um "dar a ver com palavras", do que propriamente uma "surdez" do método poético de João Cabral de Melo Neto.” (SUSSEKIND, 1998, p. 33)

16 Para uma recuperação histórica da larga utilização dos versos octossilábicos com andamentos binários por românticos brasileiros, em especial Castro Alves, remeto a Péricles

Revista Letras, Eugênio da Silva Ramos (1959).

Curitiba, UFPR, 
deslocamento enunciativo no poema, indicam-se aí os dois elementos (nós e todos) que permitirão, na sequência, uma discussão a propósito dos específicos modos de inserção de elementos líricos mesmo nos primeiros livros no escritor do "antilirismo". ${ }^{17}$

Mesmo que se considerem suas conhecidas restrições às poéticas oitocentistas, em especial de poetas brasileiros, não parece haver algo a se estranhar no fato de que, nos dois momentos do poema em que se fazem alusões explícitas à constituição de algum tipo de subjetividade em enunciação (ou em interlocução, ou em contraponto), seja utilizado um andamento binário (alternando-se as tônicas e átonas na produção de pés de duas sílabas), a partir de versos octossilábicos. O poema dialoga, nesse sentido, com uma tradição que é constitutiva do repertório do leitor brasileiro, seu público primeiro (detalhe importante nas reflexões de Cabral). ${ }^{18}$

Paulo Henriques Britto, em interlocução com poetas e críticos que entendem a adoção de formas fixas ${ }^{19}$ por poetas do século XX como "volta ao sublime" (retorno que, se tivesse havido, necessariamente deveria ser lido sob juízo negativo, acrescento) descreve os diferentes modos pelos quais a recuperação de um padrão métrico pode significar, em um poema: pode significar como a adoção de versos heroicos que emprestasse uma específica empostação a um conjunto de versos; ou significar como um tipo de ironia situacional em que o verso escolhido produzisse tensões em relação aos demais

17 A postulação, evidentemente, não é nova, nem mesmo em se tratando dos primeiros livros de Cabral. Na abertura de um capítulo em que propõe a reconsideração da "má compreensão" de Pedra do Sono, John Gledson assim se manifesta: "A posição de João Cabral de Melo Neto como o principal poeta de sua geração é incontroversa. Entretanto, pareceme que o valor de boa parte da volumosa produção crítica sobre ele fica diminuído por uma simplificação generalizada, que foi às vezes encorajada pelo próprio poeta, que enfatiza a natureza "clara", "construída", "concreta" e "objetiva" da poesia de João Cabral, depreciando qualquer sugestão de subjetividade, acaso ou inspiração. Esta visão do poeta como um calculista de efeitos naturalmente faz parte de uma tradição importante da poesia moderna (...). No entanto, essa visão é, ao menos em sua forma extrema, um mito, que talvez seja útil para o poeta, mas que submete o crítico a uma camisa-de-força desnecessária”. (GLEDSON, 2003, p.170)

18 É de se esperar que um poeta da estatura de João Cabral tivesse sido leitor da poesia brasileira do século XIX, a que se refere, aliás, quase sempre com tanta indisposição. Parece, de todo modo, muito problemática a concepção de que toda a complexidade implicada no processo criativo derive de decisões conscientes sobre as quais um escritor pode ter pleno domínio e controle, como ponderava Umberto Eco pensando seu processo de escrita de O nome da rosa: "Quando o escritor (ou o artista em geral) diz que trabalhou sem pensar nas regras do processo, quer dizer apenas que trabalhava sem saber que conhecia a regra. Uma criança fala muito bem a língua materna, mas não saberia escrever a sua respectiva gramática. Mas o gramático não é o único que conhece as regras da língua, porque estas, sem saber, a criança conhece muito bem: o gramático é apenas aquele que sabe como e por que a criança conhece a língua." (ECO, p. 14, 1985)

19 Aqui, especificamente, o verso octossilábico romântico, de emprego muito frequentemente lírico. Leia-se "lírica amorosa", como praticada por Castro Alves, por exemplo. 


\section{F. F. W. RICIERI}

Conservar na palma o peso de uma mão: ritmo, lirismo e memória em João Cabral de Melo Neto recursos técnicos de um dado texto ${ }^{20}$. Essa discussão tem grande relevância para a reflexão sobre poemas de João Cabral, em especial por se tratar de escritor que teorizou de modo tão enfático a respeito de seu próprio "projeto de escrita" que pode parecer algum tipo de heresia deixar de acompanhar todas essas formulações de um "autor" (em regime de autoridade), que passaria, assim, a ter um certo tipo de exclusividade quanto à reflexão crítica sobre seus versos. Também disso discorda Britto:

Para dar apenas um exemplo, no "Prefácio interessantíssimo", Mário afirma que o verso livre, ao evitar as formas oracionais completas e privilegiar sintagmas nominais e verbos no infinitivo, trabalha com harmonia em vez de melodia (...). Basta uma breve reflexão para que se levante a objeção óbvia: a linguagem humana, em prosa ou em verso, com ou sem recursos tradicionais, é inevitavelmente linear. Apesar de toda a argumentação de que Mário se vale para escapar dessa crítica, que espertamente ele já antecipa, o fato é que harmonia é precisamente o recurso musical que a poesia não pode imitar. Uma escansão cuidadosa de um punhado de poemas da Pauliceia desvairada revela algo bem menos revolucionário: a utilização de ritmos tradicionais, até mesmo versos perfeitamente métricos de vez em quando, porém sem haver um metro regular que vigore por todo o poema. $\mathrm{O}$ próprio Bandeira já havia chamado a atenção de Mário para esse fato, como lembra Chociay. ${ }^{21}$

Para dar sequência às implicações da constituição da estrofe em discussão, seria necessário examinar, ainda, um tipo específico de marcação desses versos (destacados dos demais pela sinalização contida nos parênteses):

\footnotetext{
(Em certas tardes nós subíamos ao edifício. A cidade diária, como um jornal que todos liam, ganhava um pulmão de cimento e vidro).
}

Revista Letras,

Curitiba, UFPR, n. 102, pp. 171-197, jul./dez. 2020 ISSN 2236-0999 (versão eletrônica)
20 Talvez seja relevante indicar o ponto de chegada da argumentação de Britto, ou seja, mais do que um certo modo de se pensarem padrões acentuais em escritas do século $\mathrm{XX}$, seu estudo evidencia alguns dos pressupostos teóricos implicitados em postulados críticos: "Creio que seria possível afirmar, sem cometer nenhuma injustiça, que por trás do preconceito contra o verso formal está uma outra visão de senso comum à qual nem mesmo poetas e críticos sofisticados são de todo imunes: as formas tradicionais seriam, além de apenas limitadoras, "artificiais"; e o verso livre (sempre encarado como uma forma única) seria não apenas livre como também "natural", permitindo ao poeta se exprimir de modo direto, sem artifícios antiquados."(BRITTO, 2014, p. 38)

21 BRITTO, 2014, p. 29. 
Em um estudo sobre a presença de "molduras" em poemas modernos e contemporâneos ${ }^{22}$, Fabiane Renata Borsato recupera um texto em que João Cabral comenta o processo por meio do qual Joan Miró ${ }^{23}$ teria progressivamente conquistado o que seria uma "atitude psicológica" diante de seu próprio processo criativo. Cotejando procedimentos adotados pela pintura renascentista e por Miró, Cabral pensaria a relação entre o artista e o olhar de seu público - que o trabalho do primeiro deveria, de algum modo, direcionar. Recorrendo, ainda, a Ortega y Gasset, Borsato assim delimita o problema:

\footnotetext{
Desse modo, é possível afirmar que há, pelos menos, dois movimentos promovidos pela moldura, sendo um deles aquele que aponta para o objeto estético, para sua estrutura, forma e disposição; outro que se dirige ao espectador/leitor, convidado a participar do espaço estético e de um jogo que tem por regras a linguagem artística e as referências do receptor. Esse duplo movimento oferece à moldura o papel dialético de conciliar texto e contexto, projetar sobre o objeto uma atenção preferencial, oferecendo-lhe um novo olhar, diferente daquele dispensado para as coisas rotineiras. $^{24}$
}

A despeito de apontar sua presença nas mais diferentes manifestações artísticas, Borsato explora a presença de procedimentos que atuariam como molduras em poemas do período delimitado pelo artigo, em poetas como Drummond, Cláudia Roquette-Pinto, Joan Brossa, Arnaldo Antunes e o próprio João Cabral de Melo Neto. Considerados os dois movimentos descritos no trecho transcrito (um voltado para o objeto estético; outro dirigido ao espectador/leitor), discerne no aproveitamento do branco do papel, em mudanças de estrofe, em cesuras do poema, no modo de principiar ou finalizar um texto, recursos que mobilizariam a problemática da moldura:

No que se refere aos estudos da moldura no poema, é possível

\footnotetext{
22 BORSATO, Fabiane Renata. Estudo da moldura em poemas modernos e contemporâneos. Dossiê temático: Os limites da poesia. InterteXto, p. 14-33, v.11, n. 02, 2018.

23 Recorrendo ao e-dicionário de Carlos Ceia: "Pausa no interior de um verso. Na métrica tradicional, esta pausa era obrigatória, sendo ditada pelo ritmo imposto ao verso. Não deve ser confundida com pausa de leitura, que é variável de leitor para leitor. Os versos curtos (até cinco sílabas) não estão, normalmente, sujeitos a cesura. Nos versos longos, pode ocorrer no princípio ("Cantei; || mas se me alguém pergunta quando", Camões), no meio ("é ferida que dói, || e não se sente", Camões) ou perto do fim do verso ("enquanto não quiserdes vós, || Senhora”, Camões). A posição medial é a mais comum. É possível um verso conter mais do que uma cesura ("olhe o céu, || olhe a terra, || ou olhe o mar", Sá de Miranda). A cesura é muitas vezes marcada pela pontuação.” In: https://edtl.fcsh.unl.pt/encyclopedia/ cesura/

24 BORSATO, 2018, p.16.
} 


\section{F. F. W. RICIERI}

Conservar na palma o peso de uma mão: ritmo, lirismo e memória em João Cabral de Melo Neto afirmar que, inúmeras vezes, ela não se limita a ser fronteira entre o real e a obra, mas integra o corpo do poema, sendo parte de sua linguagem. Há evidências disso em poemas que apresentam elementos gráficos que assumem o papel de moldura, tais como parênteses, aspas, travessão. As estrofes marcadamente isoladas das demais também funcionam como quadros emoldurados pelos espaços brancos da página. Há ainda a moldura semântica, representada por palavras reiteradas no poema que instauram contornos em versos e períodos, por meio de paralelismos por similitude ou contraste..$^{25}$

"O engenheiro" é o poema analisado no artigo para discutir a adoção do recurso às molduras por João Cabral de Melo Neto. Borsato encontra várias possibilidades de pensar sua utilização naquele poema ${ }^{26}$. Páginas atrás, indiquei, também, a propósito da primeira estrofe, que os versos enumerativos ( 1 e 4 ) emolduravam a presença do engenheiro, situada nos versos intermediários. Sem discordar, portanto, quanto a isso, das formulações do texto que venho recuperando, restringirei minha reflexão sobre o problema técnico da moldura ao modo como ele se apresenta na terceira estrofe, pelo isolamento, em relação ao conjunto, daqueles quatro específicos versos. É sabido que o recurso de destacar uma estrofe, um verso, por vezes todo um segmento de poema pela utilização dos parênteses, é muito frequente na
Revista Letras,

Curitiba, UFPR,

n. 102, pp. 171-197,

jul./dez. 2020

ISSN 2236-0999

(versão eletrônica)
25 BORSATO, 2018, p.17.

26 Transcrevo o parágrafo que condensa a descrição principal do que seria, segundo a pesquisadora, o uso da moldura neste caso (descrição de que, em linhas gerais não discordo), assinalando, na sequência, em minha própria linha argumentativa, alguns desdobramentos analíticos talvez de outra ordem, que não são desenvolvidos no texto de Borsato (preocupado em delimitar os traços definidores do procedimento em sua utilização por um conjunto de poetas): "Na terceira estrofe, duas molduras são notáveis. A mais evidente é o parêntese que insere o eu poético (primeira pessoa do plural) na ação de subir ao edifício em construção, lido como a metáfora da própria poesia. A outra moldura, representada pela cidade diária (o epíteto sugere a trivialidade dessa cidade-moldura), dá à imagem condensada do edifício, traço de arquitetura vital, pois "pulmão de cimento e vidro", emoldurado pela cidade. Em seguida, rio e nuvens emolduram o edifício na quarta estrofe, complementando a geografia. Situado na natureza, o edifício é objeto concentrado e condensado, emoldurado por paisagens que com ele estabelecem relação de implicação, como sugere o termo "pulmão'”' Para ver a análise completa, consultar BORSATO, 2018, p. 21. 
poesia cabralina. ${ }^{27}$ Mas quais sentidos poderíamos eventualmente atribuir a sua adoção em "O engenheiro" ?28

Formulo algumas hipóteses:

"... nós subíamos ao edifício": de saída, a primeira pessoa do plural parece suportar a pressuposição de uma duplicidade de perspectivas. Uma duplicidade convergente, talvez, já que um eu dirige-se a um $t u$ (produzindo um nós em que as duas posições envolvidas se fundem). Parece propor-se, ainda, o compartilhamento de algo muito tênue, muito rarefeito, que quase se desfaz no movimento mesmo em que se enuncia. Seria a evocação de algo comum aos envolvidos (supõe-se que o seja, o poema parece explorar esse efeito ilusório; parece explorar, ainda, a produção de um endereçamento que requisita a presença, nos versos, desse $t u$ que seria, como o eu, indeterminado). A presença dessa primeira pessoa é, contudo, tão sutil que diversos comentaristas dos primeiros livros de Cabral escrevem sobre o poema "O engenheiro" sem fazer qualquer referência a essa estrofe. Não teria sido notada? ${ }^{29}$

A hesitação entre dizer e não dizer, por outro lado, se demarca já na alusão a "certas tardes", especificação de que se excluem processos adjetivos

27 Para mencionar apenas alguns dos primeiros livros, lembro que, em "Fábula de Anfion", o recurso, no primeiro segmento do poema, delimita os blocos "O deserto" e "O sol do deserto". Adiante, acomoda uma definição/reflexão a propósito da palavra "mitologia". Em "Psicologia da composição", quatro conjuntos de versos (desconsiderando-se usos em trechos menores) são alocados entre parênteses. Em "Uma faca só lâmina" três ocorrências de estrofes que se apartam do conjunto por esse sinal de pontuação, para não mencionar seu emprego em estruturas mais curtas. Os parênteses podem ser enfáticos, rítmicos (proporcionando sequenciamentos ou interrupções), explicativos, irônicos... entre muitas possibilidades.

18628 Ou, recuperando a questão que, em "O efeito de real", Roland Barthes intercala a outro problema, assim, entre parênteses: "(e que valor poderia ter um método que não considerasse a integralidade de seu objeto, isto é, no caso, toda a superfície do tecido narrativo?)" (BARTHES, 1971, p. 36).

29 A propósito desse poema, Antonio Carlos Secchin (1985) comenta as duas primeiras estrofes e depois salta para a última sem qualquer alusão à terceira. João Alexandre Barbosa menciona a recorrente aproximação entre sonho e pensamento proposta por Crespo/ Bendate e, após algumas considerações sobre o caráter metalinguístico do poema, nele assinala a presença de temas não mais derivados do mundo dos sonhos (em contato com o real). Finaliza a abordagem externalizando suas próprias dificuldades com a noção de lirismo: "O que ocorre é que o próprio princípio de construção do texto é revelado ao leitor sem escamoteações líricas e, por isso, dependendo de uma inteira reavaliação dos seus elementos componentes." (BARBOSA, 1975, p. 45. Grifo meu.) Benedito Nunes, por sua vez, destaca a figuração do "ideal de um fazer poético que substitua a pura expressão dos estados subjetivos". (NUNES, 2007, p. 28). Em Costa Lima, recuperam-se as alusões a Crespo/Bendate (que também reaparecem nos dois próximos críticos citados), o trabalho com a retificação das imagens (que também Barbosa indiretamente apontara) e, na comparação da cidade ao jornal, um indicativo do processo de "transitivação da palavra" na trajetória do escritor. (LIMA, 1995, 212-214). Merquior, em A astúcia da mímese, discerne no poema uma relativização do que seria o projeto construtivo do escritor (1972, p. 19 e 20) e Cristina Henrique da Costa, recorrendo a estudo de Eucanaã Ferraz, centra suas considerações nas relações entre poesia e arquitetura na produção do poeta, tomando o poema como "homenagem ao onirismo utopista de Le Corbusier" (COSTA, 2014, 239244). Dentre esses e outros críticos que analisaram ou fizeram referências mais pontuais ao poema, Fabiane Renata Borsato, no estudo citado, foi a única a mencionar especificamente a terceira estrofe: "...o parêntese que insere o eu poético (primeira pessoa do plural) na ação de subir ao edifício em construção, lido como a metáfora da própria poesia”. (BORSATO, 2018, p. 21). 


\section{F. F. W. RICIERI}

Conservar na palma o peso de uma mão: ritmo, lirismo e memória em João Cabral de Melo Neto e que parece coincidir com aquilo que, em outro contexto, John Gledson descreveu como "um tom linguístico que permanece extraordinariamente indeterminado" ${ }^{30}$. A ação relatada, talvez de modo paradoxal, por ser muito vaga e imprecisa, parece resultar em um tom ainda mais particular, ainda mais pessoal. Isso a que se refere essa formulação inicial (com que se abre a estrofe) dificilmente poderá ser plenamente atingido pelo leitor. Situando-se em uma dimensão que seria da ordem da memória (uma memória partilhada por uma subjetividade que se enuncia e outra cuja presença se convoca), aparece como algo não disponível à enunciação.

Sem poder esgotar totalmente o problema, considero pertinente referir estudo em que Paul Ricoeur se utiliza do conceito de "memória impedida" para, evocando o pensamento de Freud, referir-se àquilo que, a partir de uma situação de sofrimento psíquico $^{31}$, pode impedir o acesso a um conteúdo que - não podendo ser lembrado -, precisa ser esquecido (mas também reencenado pela repetição). Compulsão pela repetição e resistência estariam, nesse sentido, vinculadas - assim como memória e esquecimento. Havendo qualquer validade nessa associação muito sumária, o que não se enuncia no poema (o que talvez se apresente como a enunciação de uma impossibilidade de enunciação) pode vir a ser pensado como reencenação - como repetição. A terceira estrofe, nesse sentido, estaria projetada em direção a um tempo no passado em que um momento vivido em comum (e perdido?) no poema se reatualiza, não podendo ser totalmente dito, mas de algum modo atuando discursivamente. O poema constrói (ficcionaliza), assim, algo como a miragem de uma memória, um efeito de memória.

Essa específica construção está contraposta, na mesma estrofe, à vida cotidiana, à cidade diária. Mas a contemplação da cidade do alto do edifício é operação que se divide, também, em pelo menos duas (outras) perspectivas, podendo ser pensada segundo, pelo menos, dois ângulos. A cidade é lida não apenas pelos observadores incógnitos que, em algum momento distante, do alto do edifício, pareciam dela tentar se acercar. A cidade aparece, também, em analogia com um jornal lido por "todos". Há um descompasso: as pessoas que, do alto, observam a cidade não podem ver o edifício. Seria, portanto, desse outro ângulo, desse outro ponto de vista (em um sentido bem material da expressão), que o edifício poderia, talvez, ser descrito como um bloco de alvéolos de cimento e vidro, em um jogo de perspectivas. $\mathrm{O}$ edifício pode,

30 Refletindo sobre os poemas de Pedra do Sono, Gledson conclui: "O resultado, entre outras coisas, é um tom linguístico que permanece extraordinariamente indeterminado; o leitor se encontra continuamente flutuando entre o mortalmente sério e o ridículo, incapaz de decidir qual é o tom intencional do poema. Essa indeterminação constitui a verdadeira dificuldade de Pedra do Sono; um primeiro passo rumo ao entendimento do livro pode ser dado pela percepção de que a indeterminação é deliberada e não (ao menos num sentido simples) o resultado de um conflito não resolvido entre um João Cabral "objetivo" e um João Cabral "subjetivo". (GLEDSON, 2003, p. 172).

31 Ver: RICOEUR, 2007, p. 83-85.
Revista Letras,

Curitiba, UFPR, n. 102, pp. 171-197, jul./dez. 2020 ISSN 2236-0999 (versão eletrônica) 
então, desdobrar-se em dois: um no qual se está (esteve), no alto; outro que se vislumbra, a partir do baixo.

Em um livro publicado no mesmo ano que $O$ engenheiro, Carlos Drummond de Andrade sintetizava os vínculos entre a operação banal da leitura do jornal e algum tipo de alienação em relação a um mundo (uma vida) que sabidamente se perde: "Todos os homens voltam para casa. Estão menos livres mas levam jornais e soletram o mundo, sabendo que o perdem." Em seu poema, Drummond opunha uma subjetividade confrontada com o caráter dramático da realização de um projeto criativo a um mundo povoado por melancolias/mercadorias. No poema de João Cabral (e em outros do livro de 1945, como "O fim do mundo") 32, parece haver várias possibilidades de aproximações entre tais imagens. Mas, sobretudo, se a associação for válida, a memória em "O engenheiro" (ainda que truncada ou inacessível) atualizase em oposição a um movimento geral de alienação, implicitado na analogia entre a cidade (vista como um pulmão de cimento e vidro) e os homens que leem os jornais. A memória (ainda que impedida) recupera, preserva, protege algo que estaria condenado à mercantilização, ou fadado à dissipação. A subjetivação resiste à reificação. ${ }^{33}$

Os parênteses, nesse sentido, parecem reforçar uma mudança mais complexa que se explicita na alternância da posição enunciativa, no recuo (ou no desmembramento) temporal, bem como na encenação de um movimento de rememoração. O conjunto do poema divide-se, por outro lado, em duas perspectivas: a terceira estrofe, enunciada a partir desse "nós" e três outras estrofes em "terceira pessoa", organizando-se em torno da figura do engenheiro (por sua vez uma projeção). O caráter ilusório do afastamento proporcionado pela "terceira pessoa" não parece precisar ser muito desenvolvido: o engenheiro $^{34}$ é a perspectiva que organiza a maior parte do poema. É uma $v o z$ que se projeta em terceira pessoa, a partir da ficção de uma posição subjetiva que ele mesmo, enquanto imagem, organiza. E o engenheiro são pelo menos

32 "No fim do mundo melancólico / os homens leem jornais. / Homens indiferentes a comer laranjas / que ardem como o sol." (MELO NETO, 1994. p. 71).

33 Cristina Henriques da Costa defende, ainda na abertura de seu livro, o que seria uma opção política discernível no modo como a questão da subjetividade estaria posta na poética de Cabral: “(...) a questão precisa é a seguinte: se, por um lado, João Cabral começou trabalhando com a ideia de indeterminação da palavra, fez isso conscientemente. A indeterminação dos primórdios não foi para ele sinal de obscuridade. Mas, por outro lado, se o poeta trabalhou com a indeterminação, foi porque essa técnica reagia sempre bem ao seu objetivo político: chegar com ela a decisões poéticas de fundo afetivo. (...) Se a primeira verdade de João Cabral é que o sentimento é fraco quando fala, e forte quando cala, a segunda verdade é que ele não aceita totalmente este postulado racionalista segundo o qual o sentimento não tem armas para afrontar o pensamento teórico porque sentimento não sabe pensar". (COSTA, 2014, p. 32-33).

34 Engenheiro é também um destinatário inserido no tecido material do texto, como epígrafe, o engenheiro Antônio B. Baltar. 


\section{F. F. W. RICIERI}

Conservar na palma o peso de uma mão: ritmo, lirismo e memória em João Cabral de Melo Neto dois engenheiros: um do presente e outro, na quarta estrofe, também (como a estrofe 3) enunciado a partir do pretérito imperfeito. ${ }^{35}$

Nessa quarta estrofe, é referido, por fim, um último edifício, que não parece poder ser aquele com que sonha (no presente da enunciação) o engenheiro. As demarcações temporais explicitam que ao presente é acrescida essa lembrança. Muitos edifícios, talvez: um no passado (ao qual "subíamos"), um no presente, em projeto no sonho (e no pensamento do engenheiro). Mas o edifício do passado também pode ser visto de duas perspectivas (nós e todos). E o edifício da quarta estrofe é um que se ergue, como organismo ${ }^{36}$, a partir das forças da natureza. A qual dos anteriores poderíamos (se é que poderíamos) assimilá-lo?

Havendo, ainda, um último edifício: o poema - pensado agora como um jogo de perspectivas díspares, como uma proliferação. E, se há muitas perspectivas, e se elas se dinamizam mutuamente, qual adotar como a que indicia a leitura correta? Como escolher para qual centro a leitura do poema deveria convergir?

\section{Efeitos}

Escrevendo sobre como Joan Miró teria protagonizado um demorado processo de busca de autonomia compositiva em relação a uma tradição que o precedia, João Cabral (que, como se sabe, tinha o método de considerar processos criativos alheios em suas incansáveis tentativas de reflexão sobre os seus), a certa altura, propõe: "O que Miró obteve foi uma desintegração da unidade do quadro". ${ }^{37}$ Resguardadas todas as diferenças entre pintura e poesia, parece haver, nessa reflexão, um elemento a reter. Para Cabral,

\footnotetext{
O só abandono da terceira dimensão e do conceito de centro do quadro, na evolução de Miró, tem um sentido, hoje, porque o pintor não permaneceu aí; a abolição da terceira dimensão e do centro de interesse se não se acompanhava do abandono de todo aparato compositivo criado para ela, pouco, ou nada significava em favor da superfície. ${ }^{38}$
}

E mais adiante:
Revista Letras,

Curitiba, UFPR, n. 102, pp. 171-197, jul./dez. 2020 ISSN 2236-0999 (versão eletrônica) 
Nessa época, ainda distante do dinamismo posterior, o que Miró explora não é um ato temporal do espectador. É mais bem uma forma de energia, até então não descoberta: a que pode advir da colocação de uma figura numa posição tal, dentro da superfície, que produz no espectador uma sensação de que ela se vai precipitar, mudar de lugar.

Essa energia, evidentemente, é uma ilusão. A um olho não automatizado, não acostumado inconscientemente às proporções e ao equilíbrio que se adquirem na contemplação de museus e reproduções, ou melhor, a um olho selvagem, virgem dessas formas com as quais o hábito visual amoldou nossa contemplação, essa energia é imperceptível. ${ }^{39}$

Também na criação de um poema lírico, o estilhaçamento de um elemento que pôde, em outros momentos, constituir-se em núcleo a partir do qual o conjunto se organizava, implica um rearranjo de todo o edifício. Rearranjo que se volta à produção de efeitos e pode (deve) ser pensado com um problema técnico com o qual se confronta o escritor. Pensada na modernidade como aquele quadro em que Miró considerou a abolição de um centro, a lírica passou a ser descrita nos termos de uma complexa reavaliação do conceito de sujeito, não "mais encarado em termos de substância, de interioridade e de identidade", mas "em sua relação constitutiva com um exterior que o altera". ${ }^{40}$ Como escreveu Michel Collot,

(...) um eu que se queira sempre idêntico a si mesmo e senhor de si como do universo: não é nessa pretensão de autonomia de sua majestade, o Eu, que reside a pior ilusão? A verdade do sujeito não se constitui em uma relação íntima com o exterior e com o outro? O ek-stase lírico, uma vez que perde sua caução transcendente, encontra, em muitos pontos, a redefinição do sujeito pelo pensamento contemporâneo.

Se o sujeito lírico cessa de se pertencer, é porque realiza, como cada um, a experiência de um pertencimento ao outro, ao mundo, à linguagem, que a filosofia moderna e as ciências humanas nos ensinaram a reconhecer. A psicanálise revelou que o sujeito tratava, no mais secreto de si mesmo, com uma íntima estranheza, que é também a marca de sua dependência em relação ao desejo do outro. A linguística mostrou que, longe de ser o soberano de sua palavra, ele também é, em parte, submisso a ela. A feno-

39 MELO NETO, 1994, p. 698-699.

40 COLlOT, 2018, p. 52. 


\section{F. F. W. RICIERI}

Conservar na palma o peso de uma mão: ritmo, lirismo e memória em João Cabral de Melo Neto menologia salientou sua ek-sistence e sua encarnação, seu estar no mundo e para outrem. ${ }^{41}$

A propósito, talvez convenha uma última e breve parada diante de outro poema:

"Uma faca só lâmina" se organiza a partir de um alargado processo de emolduramento. Dois segmentos apresentados em itálico (marcação gráfica que os mantém apartados do restante do conjunto, como os parênteses de "O engenheiro") abrem efecham o processo poético. Entreessas duas extremidades (que podem ser lidas, ainda, como interligadas entre si precisamente por sua identidade gráfica - a última retoma a primeira), sucedem-se nove outros segmentos (sem itálico), em que se reordenam ritmicamente ${ }^{42}$ idéias fixas imagens que se vão retificando e atualizando à medida que avança o conjunto. No primeiro segmento (em itálico), uma metalepse aciona a presença de um eventual leitor ("se transformasse em parte / de vossa autonomia"). No segmento final (graficamente interligado àquele primeiro), a primeira pessoa ("da imagem em que mais / me detive, a da lâmina") encena outra metalepse (agora de autor), deixando de produzir imagens para explicitar um aspecto específico do processo de produção dessas mesmas imagens. Nas sessões intermediárias, a presença da(e) subjetividade $(\mathrm{s})^{43}$ atualizou-se por vezes como projeção em terceira pessoa ("esse homem"); por vezes pela elaboração de estruturas enunciativas que implicitam uma posição pessoal (como um adjetivo, em "máquina perversa"); ou construções admirativas como em "das mais surpreendentes / é a vida de tal faca"); ou, com grande frequência, pela inserção daquele $t u$ que a linguística da enunciação nos ensina a considerar como correlato de um eu. Para além de todos esses elementos, duas estrofes em específico oferecem ao olhar a presença da memória (de alguém e por alguém referida):

\author{
como naquela história \\ por alguém referida \\ de um homem que se fez \\ memória tão ativa \\ que pôde conservar \\ treze anos na palma \\ o peso de uma mão, \\ feminina, apertada.
}

41 COLLOT, 2018, p. 50.

42 O ritmo é onipresente no poema: em paralelismos sintáticos e sonoros, por repetições e frustrações de expectativas da mais diversa ordem, em um conjunto de recursos que não será possível desenvolver aqui.

43 Descentradas pelo jogo de perspectivas, alteradas pelas sucessivas operações de mascaramento textuais.
Revista Letras,

Curitiba, UFPR, n. 102, pp. 171-197, jul./dez. 2020 ISSN 2236-0999 (versão eletrônica) 
A presença da memória no poema (em posição e modo de estruturação sintática que também fazem com que essas estrofes se destaquem em relação ao conjunto - em moldura) é descrita como ativa. Como algo que se produz deliberadamente por um sujeito que se empenha em conservar - no corpo - o traço remanescente de algo que se perdeu. A memória: um gesto mínimo, próximo do indizível, uma forma de resistência na e pela emoção. A memória supõe, ainda, um problema técnico. Ora, no poema, não há antes, assim como não há depois. O que se marca como passado está exatamente ao lado do que (em simultaneidade com aquilo que) se encena como presente. A representação do tempo, no poema, é ilusória, apenas uma produção de efeito.

Estamos tratando com um quadro sem profundidade: no entanto, cada nuance, cada produção de perspectiva, aquela específica metalepse (que insere uma história no tecido de outra história, superpõe o relato de um à lembrança de outro) ... cada elemento interfere no(s) sentido(s) que se pode(m) atribuir ao conjunto e a cada uma de suas componentes - não sendo perceptíveis, de todo modo, ao "olho selvagem". Porque as marcas temporais, as hesitações produzidas pela sobreposição (e pelo confronto) de posições, a encenação de repetições obsessivas e aparentemente inexplicáveis, sendo problemas técnicos, são problemas técnicos dirigidos ao leitor. ${ }^{44}$

As três últimas estrofes de "Uma faca só lâmina" (repito: contidas em uma sessão que se entrelaça com outra - na abertura do poema e se intercala, em contraponto, com outras nove, em jogo de perspectivas) encerram-se enunciando uma "lembrança" que teria vestido "tais imagens". Lembrança mais intensa "do que pôde a linguagem":

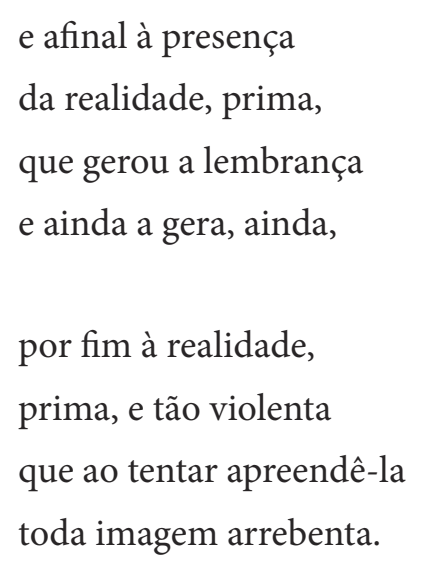

Se o poema se encerra postulando sua gênese em uma "lembrança" e seu fechamento em uma espécie de explosão ou implosão da imagem, os versos

44 Ainda, quanto a Miró: "Através dessa luta entre vosso costume e sua surpresa essencial, de cada milímetro, essas linhas se apoderam de vossa atenção. Elas sujeitam vossa atenção, acostumada a querer adivinhar as linhas, e a mantêm presa através de uma série ininterrupta de pequenas e mínimas surpresas. Aqui, vossa memória não ajuda vossa contemplação, permitindo-vos adivinhar uma linha da qual apenas percebestes um primeiro movimento. Aqui não podeis adivinhar, isto é: dispensar nada. O percurso tem que ser feito, e isso só pode se realizar dinamicamente". (MELO NETO, 1994, p. 705) Grifos meus. 


\section{F. F. W. RICIERI}

Conservar na palma o peso de uma mão: ritmo, lirismo e memória em João Cabral de Melo Neto finais formalizariam uma declaração de falência da linguagem (?), a colocação da linguagem sob suspeita (?), um retorno às coisas (?), a desagregação da metáfora (?), a declaração do caráter surpreendente e arrebatador da realidade (?). Entre outras formulações equivalentes, que reaparecem nas reflexões suscitadas pelo poema ou por poemas afins...

Ocorre que apenas os dispositivos retóricos de funcionamento de um poema lírico (sua disposição enunciativa, os deslocamentos temporais e espaciais que se podem marcar no discurso, as metalepses, as preterições, as ênfases e denegações, os recursos produtores de ritmo, a utilização de procedimentos analógicos, o modo de ordenação de imagens) podem permitir aquele embate com um leitor a todo tempo convocado a participar de uma experiência que é, ainda, da ordem da palavra. Jean Michel Maulpoix advertia, em um ensaio de 2009, que o lirismo não pode ser pensado como crítico apenas por algum tipo de perturbação que ele produza na linguagem. Ele o seria, mais radicalmente, "pela interrogação à qual ele induz o leitor: um poema é um texto que conduz aquele que lê a se colocar questões sobre a linguagem"45.

O raciocínio parece coerente com o modo como João Cabral escreve sua poesia e também com o modo como, sobre ela, ele teoriza. Então, como sustentar uma relação ingênua com a palavra "realidade", postada na estrofe final, em um poema que, durante longos onze segmentos, produziu um consistente e complexo tensionamento crítico (um tensionamento da linguagem proposta como formulação de transitividade), um poema que nos desafiou verso após verso? Não estaríamos, apenas, novamente, ainda, diante de algo como um "efeito de real" (?):

Semioticamente, o "detalhe concreto" é constituído da colusão direta de um referente e de um significante; o significado é expulso do signo, e com ele, bem entendido, a possibilidade de desenvolver uma forma do significado, isto é, na realidade, a própria estrutura narrativa (...). Isto é o que se poderia chamar ilusão referencial. A verdade dessa ilusão é a seguinte: suprimido da enunciação realista, a título de significado de denotação, o "real" volta para ela, a título de significado de conotação; pois no mesmo instante em que esses detalhes são supostos denotarem diretamente o real, eles não fazem mais do que o significarem, sem dizê-lo: o barômetro de Flaubert, a pequena porta de Michelet, não dizem mais do que isto: somos o real; é a categoria do "real" (e não seus conteúdos contingentes) que é então significada; ou melhor, a própria carência do significado em proveito do único referente torna-se o próprio significante do realismo: produz-se um efeito de real, fundamento desse inverossímil inconfessado que forma a estética de todas as obras correntes da modernidade. ${ }^{46}$
Revista Letras,

Curitiba, UFPR, n. 102, pp. 171-197, jul./dez. 2020 ISSN 2236-0999 (versão eletrônica)
45 MAULPOIX, 2009, p. 29.

46 BARTHES, 1988, p. 43. 
Essas considerações não parecem desqualificar as anotações de Marly de Oliveira sobre a hipótese de que a ausência em torno da qual se contorce "Uma faca só lâmina" pudesse ser associada a uma decepção amorosa (do autor). Ou repudiar a possibilidade de que um crítico qualquer localizasse, em dado verso, o fantasma do poeta (empírico) insone. Por que João Cabral não se posiciona contra qualquer dado humano que possa constituir experiência prévia (ou posterior) ao poema - esse apenas não é seu foco (esse é o elemento que ele se dá ao luxo de até mesmo esquecer ${ }^{47}$ enquanto se debruça sobre as questões propriamente técnicas acontecendo no poema sobre sua mesa - um poema que se quer construir como endereçado a alguém). Parece que seria o caso de recuperar, ainda, aquela tensão descrita por Dominique Combe em um ensaio no qual historia as transformações do conceito de "sujeito lírico", passando pela impossibilidade de sua descrição estável, pelo eventual acolhimento de recuperações/transformações do vivido, chegando, por fim, à formulação do que seria seu valor performativo ("o sujeito lírico se cria no e pelo poema") ${ }^{48}$. De resto, sempre problemático.

Uma leitura atenta dos diferentes argumentos que foram sendo acionados ao longo deste texto talvez permita inferir que as relações estabelecidas, na poesia de João Cabral, entre naturalidade e artifício, música e linguagem, sujeito e objeto, referencialidade e emoção, criação e tradição, trabalho e espontaneísmo, projeto e "canteiro de obras"49, forma e experiência talvez sejam bem mais complexas do que alguns dos juízos assentados sobre essa escrita poderiam permitir supor. Waltencir A. de Oliveira, em um estudo publicado em 2012, já reivindicava, desde o título de seu trabalho, que "a tensão e a dualidade atravessam [essa] poética como um todo, em um jogo sempre reversível de tendências que a todo momento se esbatem" ${ }^{\text {"50 }}$.

Se a continuidade da reflexão sobre paradigmas teóricos da crítica (em sua historicidade e condições de possibilidade, com as respectivas decorrências analíticas); se a continuidade da reflexão teórica a propósito de conceitos e termos descritivos como lírica, sujeito lírico, desaparecimento ilocutório, poesia pura, memória, ritmo, tal como tais elementos se possam apresentar em uma peça de criação (o poema), podem (devem) continuamente se reconfigurar, então não terá sido ocioso reexaminar um poema (ou dois). Talvez nunca seja ocioso, de resto, reexaminar o que quer que seja.

Aqui não podeis adivinhar, isto é: dispensar nada. O percurso tem que ser feito, e isso só pode se realizar dinamicamente.

47 Esquecer, contraparte do lembrar - assinalava Paul Ricoeur (2007).

48 COMBE, 2009, 128.

49 Para esse elemento (que não pude desenvolver) indico artigo mencionado: "O canteiro do poeta-arquiteto: a conduta criativa de João Cabral de Melo Neto à luz de seus manuscritos". (ROCHA, 2012).

50 OLIVEIRA, 2012, p. 147. 


\section{F. F. W. RICIERI}

Conservar na palma o peso de uma mão: ritmo, lirismo e memória em João Cabral de Melo Neto

\section{Referências}

BARBOSA, João Alexandre. A imitação da forma - uma leitura de João Cabral de Melo Neto. São Paulo: Duas Cidades, 1975.

BARTHES, Roland. O efeito de real. In: O rumor da língua. Trad. Mário Laranjeira. São Paulo: Brasiliense, 1988.

BORSATO, Fabiane Renata. Estudo da moldura em poemas modernos e contemporâneos. InterteXto, v.11, n. 2, p. 14-33, 2018. Dossiê temático: Os limites da poesia.

BRITTO, Paulo Henriques. O natural e o artificial: algumas reflexões sobre o verso livre. Elyra - Revista da Rede Internacional Lyracompoetics, n. 3, p. 2741, 2014.

CAWS, Mary-Ann. Poème long, poème court: sujet en cloture. In: RABATÉ, Dominique et al. Le sujet lyrique en question. Bordeaux: Presses Universitaires de Bordeaux, 1996. p. 69-82.

CHOCIAY, Rogério. Teoria do verso. São Paulo: MacGraw-Hill do Brasil, 1974.

COLLOT, Michel. A matéria-emoção. Rio de Janeiro: Oficina Raquel, 2018.

COSTA, Cristina Henrique da. Imaginando João Cabral imaginando. Campinas, SP: Ed. UNICAMP, 2014.

CRESPO, Angel e BEDATE, Pilar Gomes. Realidad y forma en la poesia de João Cabral de Melo Neto. Revista de Cultura Brasileña, t.III, n.8, p. 21, mar. 1964.

ECO, Umberto. Pós-escrito a O nome da Rosa. Rio de Janeiro: Nova Fronteira, 1985.

FERRAZ, Eucanaã. Máquina de comover: a poesia de João Cabral de Melo Neto e suas relações com a arquitetura. Rio de Janeiro: Faculdade de Letras UFRJ, 2000.

GENTIL, Hélio Salles. Introdução. In: RICOEUR, Paul. Tempo e Narrativa. Trad. Cláudia Berliner. São Paulo: Martins Fontes, 2012.
Revista Letras,

Curitiba, UFPR, n. 102, pp. 171-197, jul./dez. 2020 ISSN 2236-0999 (versão eletrônica) 
GLEDSON, John. Influência e impasses: Drummond e alguns de seus contemporâneos. Trad. Frederico Dentello. São Paulo: Companhia das Letras, 2003.

GODOY, José Roberto de Araújo. Dois cães como objeto: elementos surrealistas. Aproximações com o cinema. 2009. Dissertação (Mestrado em Teoria Literária) - Universidade Federal de São Paulo, São Paulo, 2009.

LIMA, Luiz Costa. A traição consequente ou a poesia de Cabral. In:

Lira e antilira. Rio de Janeiro: Civilização Brasileira, 1982.

MAULPOIX, Jean Michel. Pour un lirisme critique. Paris: José Corti, 2009.

MELO NETO, João Cabral de. Obra completa. Rio de Janeiro: Nova Aguilar, 1994.

MERQUIOR, José Guilherme. A astúcia da mimese (ensaios sobre lírica). Rio de Janeiro: José Olympio, 1972.

NUNES, B. João Cabral: a máquina do poema. Brasília: Ed. Universidade de Brasília, 2007.p. 15-16.

OLIVEIRA, Waltencir Alves. O gosto dos extremos: tensão e dualidade na poesia de João Cabral de Melo Neto, de Pedra do Sono a Andando Sevilha. São Paulo: Edusp, FAPESP, 2012.

RAMOS, Péricles Eugênio da Silva. Os princípios silábico e silábico-acentual. In: O verso romântico e outros ensaios. São Paulo: Conselho Estadual de Cultura, 1959.

RICOEUR, Paul. A memória, a história, o esquecimento. Campinas, SP: Ed. UNICAMP, 2007.

ROCHA, Francisco J. G.L. O canteiro do poeta-arquiteto: a conduta criativa de João Cabral de Melo Neto à luz de seus manuscritos. Revista IEB, São Paulo, n. 55, p. 127-147, 2012.

SALDIVAR, Gustavo Suertegaray. A poesia de João Cabral de Melo Neto e a arquitetura moderna: leituras cruzadas. 2012. Dissertação (Mestrado em Letras) - Pontifícia Universidade Católica de Rio Grande do Sul, Porto Alegre, 2012. 
F. F. W. RICIERI

Conservar na palma o peso de uma mão: ritmo, lirismo e memória em João Cabral de Melo Neto
SECCHIN, A. C. A poesia do menos. São Paulo: Duas Cidades; Brasília: INL, Fundação Nacional Pró-Memória, 1985.

Submetido em: 28/09/2020

Aceito em: 4/11/2020 